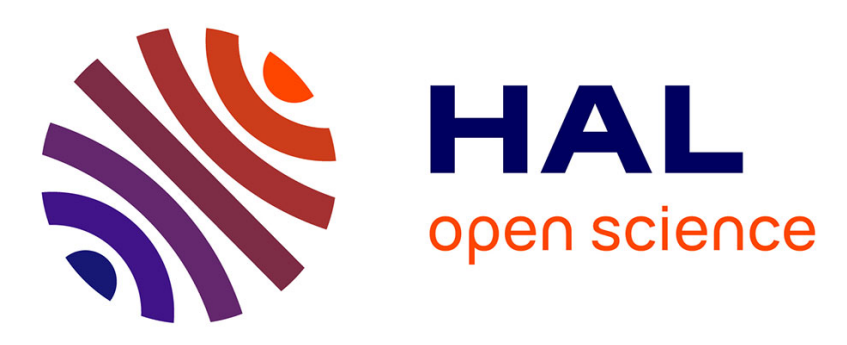

\title{
Numerical quantification of sources and phase partitioning of chemical species in cloud: Application to wintertime anthropogenic air masses at the Puy de Dôme station
}

Maud Leriche, R. Lyana Curier, Laurent Deguillaume, Dimitri Caro, Karine Sellegri, Nadine Chaumerliac

\section{To cite this version:}

Maud Leriche, R. Lyana Curier, Laurent Deguillaume, Dimitri Caro, Karine Sellegri, et al.. Numerical quantification of sources and phase partitioning of chemical species in cloud: Application to wintertime anthropogenic air masses at the Puy de Dôme station. Journal of Atmospheric Chemistry, 2007, 57, pp.281-297. 10.1007/s10874-007-9073-y . hal-00987584

\section{HAL Id: hal-00987584 https://hal.science/hal-00987584}

Submitted on 6 May 2014

HAL is a multi-disciplinary open access archive for the deposit and dissemination of scientific research documents, whether they are published or not. The documents may come from teaching and research institutions in France or abroad, or from public or private research centers.
L'archive ouverte pluridisciplinaire HAL, est destinée au dépôt et à la diffusion de documents scientifiques de niveau recherche, publiés ou non, émanant des établissements d'enseignement et de recherche français ou étrangers, des laboratoires publics ou privés. 


\section{Manuscript}

\section{Numerical quantification of sources and phase partitioning of chemical species in cloud: Application to wintertime anthropogenic air masses at the Puy de Dôme station}

Maud Leriche ${ }^{\$, £}$, R. Lyana Curier ${ }^{\#}$, Laurent Deguillaume*, Dimitri Caro ${ }^{\&}$, Karine Sellegri and Nadine Chaumerliac

Laboratoire de Météorologie Physique, Centre National de la Recherche Scientifique, Blaise Pascal University, 24 avenue des Landais, 63177 Aubière Cedex, France

\footnotetext{
${ }^{\$}$ Corresponding author. Tel.: +33-561-33-27-55; fax: +33-561-33-27-90.

${ }^{£}$ Now at LA, CNRS, Paul Sabatier University, 14 avenue Edouard Belin, 31400 Toulouse, France E-mail address: maud.leriche@aero.obs-mip.fr.

\# Now at TNO Defence Security and Safety, Electro-Optics group, P.O. Box 96864 JG,The Hague, The Netherlands

${ }^{\ddagger}$ Now at Leibniz Institute for Tropospheric Research, Permoserstrasse 15, 04318 Leipzig, Germany

${ }^{\&}$ Now at LSCE/IPSL, CEA/CNRS, Versailles Saint-Quentin University, Orme de Merisiers, Bat. 701, 91191 Gif-sur-Yvette Cedex, France
} 


\section{Abstract}

The Model of Multiphase Cloud Chemistry M2C2 has recently been extended to account for nucleation scavenging of aerosol particles in the cloud water chemical composition. This extended version has been applied to multiphase measurements available at the Puy de Dôme station for typical wintertime anthropogenic air masses. The simulated ion concentrations in cloud water are in reasonable agreement with the experimental data. The analysis of the sources of the chemical species in cloud water shows an important contribution from nucleation scavenging of particles which prevails for nitrate, sulphate and ammonium. Moreover, the simulation shows that iron, which comes only from the dissolution of aerosol particles in cloud water, has a significant contribution in the hydroxyl radical production. Finally, the simulated phase partitioning of chemical species in cloud are compared with measurements. Numerical results show an underestimation of interstitial particulate phase fraction with respect to the measurements, which could be due to an overestimation of activated mass by the model. However, the simulated number scavenging efficiency of particles agrees well with the measured value of $40 \%$ of total number of aerosol particles activated in cloud droplets. Concerning the origin of chemical species in cloud water, the model reproduces quite well the contribution of gas and aerosol scavenging estimated from measurements. In addition, the simulation provides the contribution of in-cloud chemical reactivity to cloud water concentrations.

Keywords: aerosol particles, cloud chemistry, droplets nucleation, Puy de Dôme station 


\section{Introduction}

For several years, significant efforts were made by the scientific community to understand tropospheric chemistry. However, these investigations have been mainly focused on homogeneous gas phase chemistry, which is currently well documented (Atkinson et al., 2004; 2006). At a global scale, cloud chemistry has a potential impact on the atmospheric oxidizing capacity and on climate change via the indirect effect of aerosols on the radiative budget of the earth's system, which is still poorly understood and is a major source of uncertainties in climate forecasting (Ramaswamy et al., 2001). Some modeling studies have attempted to assess the overall impact of cloud chemistry on global atmospheric composition and climate with a particular focus on the ozone chemistry (Lelieveld and Crutzen, 1991; Liang and Jacob, 1997; Barth et al., 2002) and on the sulfur cycle (Dentener et al., 2002; Kreidenweis et al., 2003). However, the details of in-cloud processes are still poorly understood and some new aspects of cloud chemistry have recently been put forward concerning for instance its potential contribution to the formation of secondary organic aerosol particles (Blando and Turpin, 2000; Gelencsér and Varga, 2005; Carlton et al., 2006). More efforts are needed to improve our understanding of the cloud impact at local scale critical for radiative and health effects, in particular via integrated modeling and in-situ studies.

A cloud is a multiphase system comprising a gaseous phase, a particulate phase, and an aqueous phase. To assess the role of cloud chemistry at a local scale, interactions between gases, cloud droplets and aerosol particles have to be taken into account in numerical cloud chemistry models. The interactions between aerosol particles and cloud droplets are usually not considered in cloud chemistry models (Ervens et al., 2003; Williams et al., 2002). Aerosol particles contribute to the chemical composition of cloud droplets by nucleation and impaction scavenging followed by dissolution of soluble 
compounds. During the cloud lifetime, the cloud chemistry leads to the formation of new chemical species with relatively low volatility such as inorganic and organic acids, which can modify the physico-chemical properties of aerosol particles after the cloud dissipates (Feingold and Kreidenweis, 2002; Yin et al., 2005) and lead to secondary organic aerosols formation (Gelencsér and Varga, 2005). For some chemical species, aerosol particles dissolution is the only source in cloud droplets; an example is transition metal ions, and in particular iron, which is well known to play a major role in the oxidizing capacity of clouds (Deguillaume et al., 2004; 2005). Study of such complex interactions needs laboratory experiments for kinetics and thermodynamics database development and modelling efforts integrating in-situ measurements.

In this framework, the Model of Multiphase Cloud Chemistry model (M2C2) (Leriche et al., 2003; Deguillaume et al., 2004) has recently been developed to simulate aerosol particles temporal evolution and their activation in cloud droplets. This cloud chemistry model includes aerosol particles, cloud microphysics and chemistry in both aqueous and gas phases. While measurements do not allow the determination of the origin of the different sources of chemical species in the cloud water and to identify these sources, the model provides this information as well as the main chemical production pathways and the impact of cloud microphysical processes on chemistry. In this study, the $\mathrm{M} 2 \mathrm{C} 2$ model is used to simulate typical wintertime anthropogenic air masses at the Puy de Dôme station. At this station, continuous measurements (http://wwwobs.univbpclermont.fr/observ/en/index.htm) as well as intensive field campaigns are performed leading to an interesting and explicit multiphase dataset including physico-chemical characterisation of air mass, aerosol particles and clouds encountered at the high altitude site. The present study aims at evaluating the role of the chemistry versus both the gas scavenging and the aerosol particles nucleation scavenging in the cloud water chemical 
composition. Then, the role of the chemistry in the phase partitioning can be determined and the various sources of chemical species inside the cloud, either from gas phase or from particulate phase are quantified.

Firstly, the model, its new developments and the initial conditions of the simulation are presented. Secondly, numerical concentrations in cloud water are compared to experimental values to assess the quality of the simulation. Then, the analysis of the different sources of chemical species in cloud water is performed. Finally, the partitioning of chemical species obtained from measurements and from simulation are compared and discussed.

\section{Model description}

\section{2-1 Model formulation}

The Model of Multiphase Cloud Chemistry (M2C2) results from the coupling (Leriche et al., 2001) between a multiphase chemistry model described in Leriche et al. (2000) and a two-moment warm microphysical scheme module predicting the number concentration of cloud droplets and raindrops and the mixing ratio of cloud water and rainwater categories using log-normal distributions (Caro et al., 2004). The dynamical framework of the model is an air parcel (Gérémy et al., 2000). The chemistry included in the chemical module is explicit. The exchange of chemical species between the gas phase and the aqueous phase is parameterized following the mass transfer kinetic formulation developed by Schwartz (1986). The aqueous phase chemistry includes the detailed chemistry of $\mathrm{HO}_{\mathrm{x}}$, chlorine, carbonates, $\mathrm{NO}_{y}$, sulphur, the oxidation of organic volatile compounds (VOCs) with one carbon atom (Leriche et al., 2003), the chemistry of transition metal ions for iron, manganese and copper (Deguillaume et al., 2004) and

Table 1 the oxalate oxidation and interaction with iron chemistry (Table 1). Oxalate represents a strong organic iron complexing agent and the highest fraction of dicarboxylic acids in 
aerosol particles (Legrand et al., 2005). The value of the accommodation coefficient for oxalic acid is estimated to be 0.05 (Leriche et al., 2000) because no measurement is available. The model considers calculations of photolysis frequencies both in the gas phase and in cloud droplets. The $\mathrm{pH}$ is calculated at each time step by solving the electroneutrality equation.

The activation of aerosol particles into cloud droplets is parameterized according to Abdul-Razzak et al. (1998) and Abdul-Razzak and Ghan (2000). Aerosol particles are represented by the sum of four log-normal distributions as follows:

$$
\frac{d N_{a p}}{d \ln a_{a p}}=\sum_{i=1}^{4} \frac{N_{a p i}}{\ln \sigma_{i} \sqrt{2 \pi}} \exp \left[-\frac{\ln ^{2}\left(a_{a p} / a_{m i}\right)}{2 \ln ^{2} \sigma_{i}}\right]
$$

Where $\mathrm{N}_{\text {ap }}$ is the total number concentrations of aerosol particles, $\mathrm{N}_{\text {api }}$ is the number concentrations of aerosol particles for each mode; $a_{\mathrm{mi}}$ is the median radius of the lognormal distribution for each mode; $\sigma_{\mathrm{i}}$ is the geometric standard deviation of the lognormal distribution of each mode and $\mathrm{a}_{\mathrm{ap}}$ is the radius of aerosol particles.

The parameterization used to allow for nucleation of cloud droplets comes down to find an expression for the maximum of the supersaturation on each model time step (AbdulRazzak et al., 1998; Abdul-Razzak and Ghan, 2000) considering the physico-chemical properties of aerosol particles and based upon the Köhler theory (Köhler, 1936; Pruppacher and Klett, 1997). For each mode, the activated fraction is calculated and leads to the number of droplets newly formed by nucleation and to the associated cloud water mixing ratio.

The introduction of the cloud droplets nucleation process in the model allows for the monitoring of the evolution of aerosol particle size distribution with time. The microphysical scheme for aerosol particles is a two-moment scheme in which the prognostic variables are the number concentration of aerosol particles and the 
corresponding volumetric concentration (Caro et al., 2004). At each time step, the evolution of aerosol particles size distribution is computed from the number of nucleated droplets and the associated activated aerosol mass. Until now, the impaction scavenging is neglected in the model, which is not very restrictive as nucleation scavenging in non precipitating clouds represents more than $90 \%$ of the total aerosol particles scavenged by the cloud droplets (Flossmann, 1991).

The impact of aerosol particles on cloud chemistry is considered in the model via the activated mass of aerosol particles. The fraction of soluble chemical species in aerosol particles is used to compute the chemical concentrations in cloud droplets of species coming from the activated particles. The mass fraction of soluble chemical species in each aerosol mode is prescribed from measurements.

\subsection{Initialization of the model: Anthropogenic air mass at the Puy de Dôme station}

The Puy de Dôme station is located in the centre of France at the summit of the Puy de Dôme Mountain (1465 $\mathrm{m}$ above sea level) and is well recognized in the scientific community (Van Dingenen et al., 2004; Putaud et al., 2004). The station is equipped with continuous measurements since June 1995 for meteorological variables and ozone; since February 1998 for radiation fluxes (UV, visible, diffusive fluxes and $\mathrm{J}\left(\mathrm{NO}_{2}\right)$ ); since May 2000 for number concentration of aerosol particles; since September 2000 for black carbon content; since November 2000 for $\mathrm{CO}_{2}$; since April 2002 for CO; since January 2003 for $\mathrm{SO}_{2}$ and $\mathrm{NO}_{\mathrm{x}}$; since April 2003 for $\mathrm{NO}_{\mathrm{y}}$; and since June 2003 for drop surface area, liquid water content and effective radius when a cloud is present on the site (free access to data from http://wwwobs.univ-bpclermont.fr/observ/en/index.htm). In addition, detailed measurements of the cloud liquid phase are made since February 2001 for selected cloud events mainly during winter and spring in the framework of the OREBEAM (Observatoire de Recherche en Environnement Biophysicochimie de l'Eau 
Atmosphérique et Modifications anthropiques) project database (http://wwwobs.univbpclermont.fr/atmos/orebeam/orebeampage1.htm) including measurements of iron (total content and oxidation state), ionic chromatography, dissolved organic carbon; conductivity, redox potential, $\mathrm{pH}$ and some biological parameters (see Amato et al., 2005). Intensive field campaigns are regularly organized at the station like the European CIME experiment (Wobrock et al., 2001) as well as various national campaigns as the 2001 Puy de Dôme campaign during winter 2001.

In order to perform a simulation of a typical wintertime anthropogenic air mass at the Puy de Dôme station with the $\mathrm{M} 2 \mathrm{C} 2$ model, a scenario based upon the air mass classification of Sellegri et al. (2003a), which defines a typical anthropogenic influenced free tropospheric air mass encountered at the station, was elaborated using the available measurements.

The air trajectory used to initialize the parcel comes from a three dimensional simulation of a typical dynamical situation corresponding to wintertime polluted air masses at the Puy de Dôme station coming from the North-North-East. This three dimensional simulation was performed with the meso-scale non-hydrostatic Clark model (Clark and Hall, 1991) using three nested grids. The trajectory used in M2C2 corresponds to the back-trajectory computed by the three dimensional model arriving at

Figure 1 noon local time at the summit of the Puy de Dôme. The trajectory is shown in Figure 1 together with the corresponding vertical wind speed. This trajectory at noon corresponds to the maximum of the photolysis leading to the highest intensive photochemistry. The beginning of the lifting of the air parcel is also indicated in Figure 1. At this moment, the $\mathrm{M} 2 \mathrm{C} 2$ simulation run was started for a duration of twelve minutes. 
The gas phase chemical species are initialized using measurements from Voisin et al. (2000), performed during the CIME experiment in winter 1997-1998. During this campaign, a large amount of chemical species was measured kin addition to continuous measurements of, e.g., ammonia and nitric acid. An event corresponding to an anthropogenic air mass arriving at the Puy de Dôme station as defined in Sellegri et al. (2003a) was selected in this database. Initial concentrations taken from this event for Table 2 gas phase chemical species are shown in Table 2.

The initialization of the physico-chemical properties of aerosol particles are derived from Sellegri et al. (2003a) and Sellegri (2002) for anthropogenic influenced free tropospheric aerosols without marine input sampled at the Puy de Dôme station. The

Figure 2 chemical composition for these aerosol particles is shown in Figure 2 for each four identified modes: Aitken, accumulation 1, accumulation 2 and coarse mode. Usually, at the Puy de Dôme station, the accumulation particles are spread in two distinct modes with different chemical signature as shown in Figure 2. As expected, the dust contribution is significant for the coarse mode whereas the organic contribution decreases with the particle size. The coarse mode appears to be acidic with a low contribution of ammonium. The initial number distribution of aerosol particles corresponding to this chemical composition are represented in Figure 3 together with the four log-normal distributions used to fit it. Starting from the left-hand side, the first fitted distribution represents the Aitken mode, the second and the third ones the two accumulation modes and the fourth one the coarse mode. Table 3 presents the physicochemical properties of aerosol particles and the fitting parameters of the number distribution used in the simulation. The density, the number of dissociated ions, the mass fraction of soluble materials, the mass fraction related to soluble mass of nitrate, sulphate, ammonium, formate, oxalate and soluble iron, and the molar mass of aerosol 
particles in each mode was derived from the aerosol particle measurements database following Sellegri (2002). The mass fraction of iron is estimated from Particle Induced X-Ray Emissions (PIXE) data (Sellegri et al., 2003a) and assuming an iron solubility of $15 \%$ (Deguillaume et al., 2005). The oxalic acid is assumed to represent $60 \%$ of total measured organic acids and formic acid, 40\%. This partitioning followed the ratio observed between dicarboxylic and mono-carboxylic acids (Sellegri et al., 2003a) if we assume that mono-carboxylic acids are mainly represented by formic acid and dicarboxylic acids by oxalic acid.

\section{Results and discussion}

3.1 Comparisons between simulated and observed cloud concentrations for main chemical species

The simulated concentrations and $\mathrm{pH}$ in cloud water are compared with observed values

Table 4 as shown in Table 4. Numerical results are averaged values on the whole simulation. Observed values are taken from previous studies using the database of chemical measurements available in cloud water at the Puy de Dôme station coming from the ORE-BEAM project mentioned above (Marinoni et al., 2004; Parazols et al., 2006), which used air mass classification similar to Sellegri et al. (2003a). The maximum value of the simulated cloud liquid water content is $0.4 \mathrm{~g} \mathrm{~m}^{-3}$ at the top of the mountain and the mean value is $0.16 \mathrm{~g} \mathrm{~m}^{-3}$. For anthropogenic influenced free tropospheric air masses, the measured cloud liquid water content is around $0.3 \mathrm{~g} \mathrm{~m}^{-3}$ and hence there is a reasonable agreement between model and measurements. Simulation and in-situ measurement indicate both acidic $\mathrm{pH}$ values for the wintertime anthropogenic air masses at the Puy de Dôme station. In general, results from the model compare favorably with the measured concentrations. However, formate and oxalate are overestimated by the model and iron is underestimated. 
For both carboxylic acids (formate and oxalate), the overestimation is about a factor 2 . However, the amplitude of this factor is quite uncertain because of the low accuracy for carboxylic acids concentrations determined by ion chromatography due to their low concentrations close to the detection limit. Overestimation of formic acid has also been obtained by the SPACCIM model applied on a continental event of the FEBUKO field campaign, which took place at the Schmücke Mountain (937m above sea level) located in central Germany in October 2001 (Wolke et al., 2005). However, the SPACCIM chemical mechanism takes into account organic acids with up to four carbon atoms and the modelled acetic acid concentrations compared well with those obtained from the FEBUKO measurements. This suggests that the observed overestimation of formic acid is not solely due to weighing formic acid as the source of mono-carboxylic acid. Measurements show that oxalic acid is the main dicarboxylic acid in aerosol particles. Moreover, recent studies have shown that, in addition to aerosol particles, chemical reactivity is an important source of oxalic acid in cloud droplets, especially in rural areas influenced by biogenic emissions (Ervens et al., 2004; Sorooshian et al., 2006). Thus, no satisfactory reason is available to explain the simulated overestimation of oxalic acid by the model.

The only source of iron in cloud droplets is from aerosol particles, hence, its underestimation is explained by: the uncertainty on measured iron concentration in aerosol particles which are often close to the detection limit; the fact that measurements of elemental species in aerosol particles were not available for all anthropogenic events used to estimate physico-chemical properties of initial aerosol particles; and the two assumptions made to estimate the iron soluble part in the particulate phase (Table 3). Measurements of iron in particles have been made using PIXE analysis which gives the elemental species concentration, the two assumptions made to estimate soluble iron 
mass fraction are: all iron in the particulate phase is iron oxide $(\mathrm{FeO})$ and the solubility of iron is $15 \%$. The first assumption could lead to an underestimation of iron mass fraction in the particulate phase depending on the real chemical species of iron which occur in various forms: iron oxides, iron hydroxides, adsorbed iron, etc...(Deguillaume et al., 2005). For the second assumption, available values of iron solubility are in the range of 0.01 to $35 \%$ depending on the occurrence of iron in a crystalline or in a carboneous matrix (Desboeufs et al., 2005) and the dissolution is instantaneous in the model although it is well known that the dissolution is a kinetic process (Deguillaume et al., 2005). Thus, the underestimation of iron by the model is still an open question.

In the model, the cloud water chemical composition is initialized by chemical species coming from the activation of aerosol particles. In this study, the whole coarse mode and accumulation mode 2 are activated, as well as a large fraction of the accumulation mode 1, and only a small part of the Aitken mode. Cloud water concentrations do not only reflect the chemical composition of activated aerosol particles which would lead to similar concentrations for nitrate and sulphate as shown by the chemical composition of aerosol particles (Figure 2). Indeed, the nitrate concentration in cloud droplets is higher than the concentration of sulphate due to the impact of chemical reactivity on cloud water concentrations as will be demonstrated later. To quantify the contribution of reactivity, the sources of chemical species in cloud water have to be determined.

\subsection{Quantifications of chemical species sources in cloud water}

While measurements do not allow determining the origin of the different chemical species in cloud water without artefacts, the model can provide this information. Analysis of the sources of chemical species (particulate, gaseous, or chemical reactivity

Table 5 in cloud water) is shown in Table 5 as relative contributions to their final concentration in the liquid phase. These results show that, for inorganic compounds, the scavenging of 
aerosol particles predominates due to the complete activation of the accumulation mode 2 and the coarse mode with the largest contribution for sulphate and ammonium.

In the cloud droplets, $72.5 \%$ of the ammonium concentration comes from the dissolution of activated aerosol particles. The $27.5 \%$ remaining comes from the gas phase, as ammonia is a very soluble gas, and it is nearly completely scavenged by the cloud water. Similar ratios are observed for sulphate, with $73 \%$ of its cloud droplets concentration coming from the dissolution of activated aerosol particles whereas the remaining $27 \%$ are chemically produced in the aqueous phase. This aqueous phase production is due to the scavenging of gaseous sulphur dioxide in cloud droplets where it is oxidized into sulphate by pernitric acid and hydrogen peroxide. Despite the high iron concentrations in cloud droplets, as Deguillaume et al. (2004) showed, the catalysis of sulphur autoxidation by iron is negligible in the formation of sulphate.

For nitrate, the situation is quite complex: $56 \%$ of the nitrate-containing cloud droplets come from activated aerosol particles, $15.5 \%$ come from the gas phase initial concentration, $23 \%$ come from a gas phase in cloud production and the remaining $5.5 \%$ come from an aqueous phase in cloud production. As nitric acid is a very soluble gas, its initial gas phase concentration and its gas phase production are completely and rapidly scavenged in cloud droplets in a similar way to ammonia. The simulated air mass has anthropogenic characteristics, hence the nitrogen oxides concentration levels are high (Table 2) and lead to a significant production of nitric acid in the gas phase and of nitrate in the aqueous phase. The main chemical pathway producing nitrate in the aqueous phase is the oxidation of sulphur dioxide by pernitric acid, which also contributes to the sulphate production (Leriche et al., 2003). This analysis of nitrate sources in cloud droplets explains the higher concentration of nitrate than sulphate in cloud droplets mentioned above (Table 4). Indeed, as the nitrate mass fraction in 
activated particles is as high as those of sulphate (Table 3) and its main aqueous phase chemical production pathway is the same as for sulphate, its higher concentration in cloud droplets may be explained by its efficient gas phase chemical production followed by its scavenging. High $\mathrm{NO}_{\mathrm{x}}$ levels lead to this efficient nitrate production, which confirms the hypothesis of Sellegri et al. (2003b) of a favoured nitrate production in cloud over sulphate under the atmospheric conditions typical of the Puy de Dôme site. In cloud droplets, iron, which is a major $\mathrm{OH}$ precursor (Deguillaume et al., 2005), come only from the dissolution of activated particles as seen before, as well as the oxalic acid which can inhibit the role of iron in the $\mathrm{OH}$ production due to its complexing ability. Introducing aerosol particles in the $\mathrm{M} 2 \mathrm{C} 2$ model allows for correctly representing the in-cloud source of these two chemical species, and thus, the in-cloud $\mathrm{OH}$ production. Analysis of the relative contribution of the main $\mathrm{OH}$ production pathways in cloud droplets shows that iron reactivity contributes $30 \%$ to the $\mathrm{OH}$ production in droplets via the photolysis of iron(III) and the Fenton reaction (Table 6) while its scavenging is the main pathway contributing 57\%. In order to study the impact of oxalate on $\mathrm{OH}$ production in cloud droplets, an additional simulation was performed neglecting oxalate in aerosol particles. Results show that, when oxalate chemistry is not considered, the contribution of iron in $\mathrm{OH}$ aqueous phase production is higher, $57 \%$, and the scavenging is less important (Table 6). Oxalate chemistry leads to a decrease in the contribution of iron in $\mathrm{OH}$ production as expected by its inhibiting role due to its high complexing power on iron. However, these results show that, even if oxalate chemistry is considered and despite a relatively low photochemical activity due to the hibernal situation, iron contributes significantly to the $\mathrm{OH}$ radical production inside the cloud.

All these results show the interest of such an approach, which allows for quantifying the relative importance of gas and aqueous phase chemistry against aerosol particles as 
source of soluble chemical species in cloud droplets by considering explicitly the chemical source coming from activated particles.

\subsection{Partitioning of chemical species among cloud phases: droplets, interstitial aerosol} particles and gas

To get a global view of chemical species in cloud, the phase partitioning between the gas phase, the particulate phase and the liquid phases is calculated for nitric acid,

Figure 4 sulphuric acid, ammonium and formic acid. Results of this analysis are shown in Figure 4, which can be directly compared to the estimated phase partitioning from

Figure 5 measurements shown on Figure 5 (adapted from Sellegri et al., 2003b) for anthropogenic influenced free tropospheric air masses sampled during the 2001 Puy de Dôme campaign in winter 2001. The experimental procedure is explained in detail in Sellegri et al. (2003b), but we will briefly summarize its principle. During a cloud event, interstitial and residual phases are separately sampled with specific inlets: Round Jet Impactor (RJI) and Counterflow Virtual Impactor (CVI, Noone et al., 1988). The gas phase is sampled using mist chambers, while the particulate phase is sampled using cascade impactors, both in the residual and interstitial phases. Moreover, the bulk liquid concentrations were measured with a CDI device (Cloud Droplet Impactor, Kruisz et al., 1993). While the contributions of gaseous, particulate and liquid concentrations to the total atmospheric concentration of a given species can be experimentally evaluated within the experimental uncertainties, it is difficult to evaluate the particulate and gaseous origin of the liquid concentration by an experimental procedure. Sellegri et al. (2003b) attempted to do this by neglecting the in-cloud chemical liquid production. The experimental gas and particulate originating liquid concentrations were deduced by combining the results from the CVI device and the results from the CDI device. The strong hypothesis in this calculation was that the fraction of gaseous species which were 
evaporating from cloud droplets was equivalent to the one which had absorbed from the original gas phase and dissolved in the liquid phase during the formation of the cloud. In the present study, it is possible to evaluate this hypothesis by modelling the fractions of gas-originating and particle-originating compounds present in the liquid phase as well as the contribution of chemical reactivity in liquid phase concentrations.

First, the model can be compared to measurements regarding the three phase apportionment (interstitial gas, interstitial particles and liquid phase). The main difference between measurements and simulation lies in the fraction of the interstitial particulate phase. This fraction is close to zero for numerical results (in black in Figure 4) whatever the chemical species considered whereas it ranges from $1 \%$ to $12.4 \%$ of the total concentration for in-situ data. Measurements showed bulk mass scavenging efficiencies for anthropogenic air mass of 0.91 for sulphate, 0.96 for nitrate and 0.88 for ammonium, no data were available for formic acid (Sellegri et al., 2003c) whereas numerical results show bulk mass scavenging efficiencies close to 1 for all species as almost all aerosol mass is activated. However, the in-situ number scavenging efficiency is between 0.4 and 0.48 which is similar to the simulated value (0.41) highlighting the ability of the model to simulate the cloud droplets nucleation process. The discrepancy in the mass scavenging efficiencies indicates an overestimation of the activated mass by the model. This drawback could be improved in the future by the implementation of the effect of organic compounds on the surface tension and on the bulk hygroscopicity of the particles following Abdul-Razzak and Ghan (2004).

With respect to measurements, in addition to gas and aerosol particles scavenging, the simulation allows to identify the chemical production sources in the liquid phase as detailed above. For an improved comparison with the partitioning obtained from measurements, the contribution of the chemical gas phase production in the liquid phase 
concentrations has been included in gas-originating liquid. For nitric acid, the fraction present in the gas phase agrees between simulation and measurements. For the liquid phase, the simulation shows a small but appreciable amount of nitrate originating from chemical production. The amount of gas and particulate originating nitrate in the liquid phase as determined from the model simulation and the measurements are within experimental uncertainties. For sulphuric acid, a direct comparison between measured and simulated results is not possible because the phase partitioning obtained from measurements is for the system $\mathrm{SO}_{2} / \mathrm{SO}_{4}{ }^{2-}$. The experimental findings that a large amount of sulphate in cloud droplets originates from particles are confirmed by the simulation. For ammonium, measured and simulated partitioning show completely different patterns: while the measured interstitial gas fraction is about $56 \%$, the simulated fraction is $1 \%$ of the total atmospheric ammonium concentration. Moreover, for measurements, the amount of gas-originating ammonium in the liquid phase is close to the particles-originating concentration, while it is three times more for the simulation. These two discrepancies could be related to high ammonium emission around the Puy de Dôme Mountain not considered in the simulation and leading to observed subsaturation of the liquid phase as underlined by Sellegri et al. (2003b). For formic acid, the simulated and measured partitioning compare well with the major contribution coming from the gas phase. Moreover, the simulation shows a negligible production in the liquid phase, which is consistent with the observations.

Finally, such a modelling approach leads to a global view of the partitioning of chemical species in clouds including the identification of their various sources. This approach is globally in quite good agreement with the measured partitioning, which makes it a valuable tool for evaluating liquid concentrations in clouds, without developing a heavy instrumental set-up. 


\section{Conclusion}

Partitioning of chemical species between the liquid, gaseous and particulate phases was simulated for typical wintertime anthropogenic air masses at the Puy de Dôme research station using the $\mathrm{M} 2 \mathrm{C} 2$ model. The $\mathrm{M} 2 \mathrm{C} 2$ model has been extended to include the aerosol particles evolution due to nucleation scavenging which is parameterized using the Abdul-Razzak and Ghan (2000) formulation. The model simulates the chemical and the microphysical evolution of clouds including the interactions between aerosol particles and chemical reactivity in both liquid and gaseous phases. Modelled chemical concentrations could be compared to measurements performed at the station during extensive field campaigns.

The comparison of the simulated and measured concentrations in cloud water shows a good agreement for major species found in droplets, i.e. for sulphate, nitrate and ammonium ions. The model and measurements agree to a smaller extent for organic acids which are overestimated and iron which is underestimated by the model. The reasons for the overestimation of organic acids are not clear and the discrepancy could be partly due to larger uncertainties in the experimental determination of organic concentrations in cloud water, compared to major ions. The underestimation of iron can be explained by the uncertainties on its measured concentration in the particulate phase and by the assumptions made for estimating its soluble fraction in aerosol particles depending on its chemical form into the particle matrix and on its solubility.

The simulated concentrations in cloud water correctly reflect the chemical composition of the activated aerosol particles. Indeed, the analysis of the sources of the chemical species in cloud water shows an important contribution from nucleation scavenging of particles which prevails for nitrate, sulphate and ammonium. However, the gas scavenging is the main source for formic acid in cloud water. The chemical reactivity is 
a significant source for nitrate and for sulphate. In addition, the calculation of $\mathrm{OH}$ production in cloud droplets shows the significant contribution from iron even if the oxalate inhibiting role is considered.

Finally, the model could further estimate which fraction of the liquid droplets was due to particulate scavenging, gas dissolution, or chemical reaction in the liquid phase. Again, results could be compared to experimental measurements performed by Sellegri et al. (2003b). Numerical results show an underestimation of the interstitial particulate phase which could be due to an overestimation of the activated mass by the model. However, the numerical number scavenging efficiency of particles is in agreement with measured value. Another important discrepancy is found for ammonium partitioning: while measurements show a predominant fraction of the species present in the interstitial gas, the simulation prevails almost all of ammonium in the liquid phase. An explanation for this discrepancy may be the large emissions of ammonium around the Puy de Dôme as suggested by measurements. In general, other results show good agreement with the partitioning obtained from measurements. Moreover, the simulation provides the quantification of chemical in-cloud production which can not be obtained directly from measurements.

In conclusion, this study shows the ability of the M2C 2 model to study the complex interactions between cloud microphysics, aerosol particles and photo-chemical reactivity. In future work, such an approach will be extended to the study of organic compounds chemistry in cloud including photochemistry and biologic pathways using the ORE-BEAM (Observatoire de Recherche en Environnement Biophysicochimie de l'Eau Atmosphérique et Modifications anthropiques) project database (http://wwwobs.univ-bpclermont.fr/atmos/orebeam/orebeampage1.htm) with special 
focus on dicarboxylic acids chemistry representing a crucial scientific issue in organic aerosol particles chemistry (Fuzzi et al., 2006).

\section{Acknowledgments}

The authors are very grateful to Wolfram Wobrock for providing the three dimensional simulation with the Clark model. This work was supported by the "Programme National de Chimie Atmosphérique" (PNCA) of the INSU (Institut des Sciences de l'Univers) and by the ORE-BEAM ("Observatoire de Recherche en Environnement Biophysicochimie de l'Eau Atmosphérique et Modifications anthropiques") project of the French Ministry for Research and Education. Computer resources were provided by I.D.R.I.S. (Institut du Développement et des Ressources en Informatique Scientifique, project $\left.n^{\circ} 000187\right)$.

\section{References}

Abdul-Razzak, H., Ghan, S. J. and Rivera-Carpio, C. 1998: A parameterization of aerosol activation, 1, Single aerosol type, J. Geophys. Res. 103, 6123-6131.

Abdul-Razzak, H. and Ghan, S. J., 2000: A parameterization of aerosol activation, 2, Multiple aerosol types, J. Geophys. Res. 105, 6837-6844.

Abdul-Razzak, H. and Ghan, S. J., 2004: Parameterization of the influence of organic surfactants on aerosol activation, J. Geophys. Res. 109, D03205, doi:10.1029/2003JD004043.

Amato, P., Ménager, M., Sancelme, M., Laj, P., Mailhot, G. and Delort, A.-M., 2005: Microbial population in cloud water at the Puy de Dôme: Implications for the chemistry of clouds, Atmos. Environ. 39, 4143-4153. 
Atkinson, R., Baulch, D. L., Cox, R. A., Crowley, J. N., Hampson, R. F., Hynes, R. G., Jenkin, M. E., Rossi, M. J. and Troe, J., 2004: Evaluated kinetic and photochemical data for atmospheric chemistry: Volume I - gas phase reactions of $\mathrm{O}_{\mathrm{x}}, \mathrm{HO}_{\mathrm{x}}, \mathrm{NO}_{\mathrm{x}}$ and $\mathrm{SO}_{\mathrm{x}}$ species, Atmos. Chem. Phys. 4, 1461-1738.

Atkinson, R., Baulch, D. L., Cox, R. A., Crowley, J. N., Hampson, R. F., Hynes, R. G., Jenkin, M. E., Rossi, M. J. and Troe, J., 2006: Evaluated kinetic and photochemical data for atmospheric chemistry: Volume II - gas phase reactions of organic species, Atmos. Chem. Phys. 6, 3625-4055.

Barth, M. C., Hess, P. G. and Madronich, S., 2002: Effect of marine boundary layer clouds on tropospheric chemistry as analyzed in a regional chemistry transport model, J. Geophys. Res. 107, doi:10.1029/2001JD000468.

Blando, J. D. and Turpin, B. J., 2000: Secondary organic aerosol formation in cloud and fog droplets: a literature evaluation of plausibility, Atmos. Environ. 34, 1623-1632.

Buxton, G. V., Salmon, G. A. and Williams, J. E., 1999: The reactivity of oxalate towards oxy-sulphur free-radicals in aqueous solution, in K. H. Becker and G. Angeletti (ed.), Air Pollution Research Report 67: Chemical mechanism of atmospheric processes, Office for Official Publications of the European Communities, Luxembourg, pp. 357-361.

Carlton, A. G., Turpin, B. J., Lim, H. -J., Altieri, K. E. and Seitzinger, S., 2006: Link between isoprene and secondary organic aerosol (SOA): Pyruvic acid oxidation yields low volatility organic acids in clouds, Geophys. Res. Lett. 33, L06822, doi:10.1029/2005GL025374.

Caro, D., Wobrock, W., Flossmann, A. I. and Chaumerliac, N., 2004: A two-moment parameterization of aerosol nucleation and impaction scavenging for a warm cloud 
microphysics: description and results from a two-dimensional simulation, Atmos. Res. 70, 171-208.

Clark, T. L. and Hall, W. D., 1991: Multi-domain simulations of the timed dependent Navier-Stokes equations: benchmark error analysis of some nesting procedure, $J$. Comp. Phys. 92, 456-481.

Deguillaume, L., Leriche, M., Monod, A. and Chaumerliac, N., 2004: The role of transition metal ions on $\mathrm{HO}_{\mathrm{x}}$ radicals in clouds: a numerical evaluation of its impact on multiphase chemistry, Atmos. Chem. Phys. 4, 95-110.

Deguillaume, L., Leriche, M., Desboeufs, K., Mailhot, G., Georges, C. and Chaumerliac, N., 2005: Transition metals in atmospheric liquid phases: sources, reactivity and sensitive parameters, Chem. Rev. 105, 3388-3431.

Dentener, F., Williams, J. and Metzger, S., 2002: Aqueous phase reaction of $\mathrm{HNO}_{4}$ : The impact on tropospheric chemistry, J. Atmos. Chem. 41, 109-133.

Desboeufs, K. V., Sofikitis, A., Losno, R., Colin, J. L. and Ausset, P., 2005: Dissolution and solubility of trace metals from natural and anthropogenic aerosol particulate matter, Chemosphere 58, 195-203.

Ervens, B., George, C., Williams, J. E., Buxton, G. V., Salmon; G. A., Bydder, M., Wilkinson, F., Dentener, F., Mirabel, P., Wolke, R. and Herrmann, H., 2003: CAPRAM2.4 (MODAC mechanism): An extended and condensed tropospheric aqueous phase mechanism and its application, J. Geophys. Res. 108, 4426, doi:10.1029/2002JD002202.

Ervens, B., Feingold, G., Frost, G. J. and Kreidenweis, S. M., 2004: A modeling study of aqueous production of dicarboxylic acids: 1. Chemical pathways and speciated organic mass production, J. Geophys. Res. 109, D15205, doi:10.1029/2003JD004387, 2004. 
Faust, B. C. and Zepp, R. G., 1993: Photochemistry of aqueous iron(III)polycarboxylate complexes: Roles in the chemistry of atmospheric and surface waters, Environ. Sci. Technol. 27, 2517-2522.

Feingold, G. and Kreidenweis, S. M., 2002: Cloud processing of aerosol as modeled by a large eddy simulation with coupled microphysics and aqueous chemistry, $J$. Geophys. Res. 107, 4687, doi:10.1029/2002JD002054.

Flossmann, A. I., 1991: The scavenging of two different types of marine aerosol particles using a two-dimensional detailed cloud model, Tellus 43B, 301-321.

Fuzzi, S., Andreae, M. O., Huebert, B. J., Kulmala, M., Bond, T. C., Boy, M., Doherty, S. J., Guenther, A., Kanakidou, M., Kawamura, K,. Kerminen, V. -M., Lohmann, U., Russell, L. M. and Pöschl, U., 2006: Critical assessment of the current state of scientific knowledge, terminology, and research needs concerning the role of organic aerosols in the atmosphere, climate, and global change, Atmos. Chem. Phys. 6, 20172038.

Gelencsér, A. and Varga, Z., 2005: Evaluation of the atmospheric significance of multiphase reactions in atmospheric secondary organic aerosol formation, Atmos. Chem. Phys. 5, 2823-2831.

Gérémy, G., Wobrock, W., Flossmann, A. I., Schwarzenböck A. and Mertes, S., 2000: A modelling study on the activation of small Aitken-mode aerosol particles during CIME 97, Tellus 52B, 959-979.

Getoff, N., Schwoerer, F., Markovic, V. M., Sehested, K. and Nielsen, S. O., 1971: Pulse radiolysis of oxalic acid and oxalates, J. Phys. Chem. 75, 749-755.

Köhler, H., 1936: The nucleus in the growth of hygroscopic droplets,Trans. Faraday Soc. 32, 1152-1161. 
Kreidenweis, S. M., Walcek, C. J., Feingold, G., Gong, W., Jacobson, M. Z., Kim, C. H., Liu, X., Penner, J. E., Nenes, A. and Seinfeld, J. H., 2003: Modification of aerosol mass and size distribution due to aqueous-phase $\mathrm{SO}_{2}$ oxidation in clouds: Comparisons of several models, J. Geophys. Res. 108, 4213, doi:10.1029/2002JD002697.

Kruisz, C., Berner, A. and Branntner, B., 1993: A cloud water samples for high wind speeds, in P. M. Borell, P. Borell, T. Cvitas, and W. Seiler (ed.), Proc. EUROTRAC Symposium 92, SPB Academic Publising bv, The Hague, pp. 523-525.

Legrand, M., Preunkert, S., Galy-Lacaux, C., Liousse, C. and Wagenbach, D., 2005: Atmospheric year-round records of dicarboxylic acids and sulfate at three French sites located between 630 and $4360 \mathrm{~m}$ elevation, J. Geophys. Res. 110, D13302, doi:10.1029/2004JD005515, 2005.

Lelieveld, J. and Crutzen, P. J., 1991: The role of clouds in tropospheric photochemistry, J. Atmos. Chem. 12, 229-267.

Leriche, M., Voisin, D., Chaumerliac, N., Monod, A. and Aumont, B., 2000: A model for tropospheric multiphase chemistry: Application to one cloudy event during the CIME experiment, Atmos. Environ. 34, 5015-5036.

Leriche, M., Chaumerliac, N. and Monod, A., 2001: Coupling quasi-spectral microphysics with multiphase chemistry: A case study of a polluted air mass at the top of the Puy de Dôme mountain (France), Atmos. Environ. 35, 5411-5423.

Leriche, M., Deguillaume, L. and Chaumerliac, N., 2003: Modeling study of strong acids formation and partitioning in a polluted cloud during wintertime, J. Geophys. Res. 108, 4433, doi: 10.1029/2002JD002950.

Liang, J. and Jacob, D. J., 1997: Effect of aqueous phase cloud chemistry on tropospheric ozone, J. Geophys. Res. 102, 5993-6002. 
Marinoni, A., Laj, P., Sellegri, K. and Mailhot, G., 2004: Cloud chemistry at the Puy de Dôme: variablility and relationships with environmental factors, Atmos. Chem. Phys. 4, 715-728.

Martell, A. E. and Smith, R. M., 1977: Critical Stability Constants. Volume 3: Other Organic Ligands, Plenum Press, New York London.

Moorhead, E. G. and Sutin, N., 1966: Rate and equilibrium constants for the formation of the monooxalate complex of iron(III), Inorg. Chem. 5, 1866-1871.

Noone, K. J., Charlson, R. J., Covert, D. S., Ogren, J. A. and Heintzenberg, J., 1988: Design and calibration of a counterflow virtual impactor for sampling of atmospheric fog and cloud droplets, Aerosol Sci. Technol. 8, 235-244.

Parazols, M., Marinoni, A., Amato, P., Abida, O., Laj, P. and Mailhot, G., 2006: Speciation and role of iron in cloud droplets at the puy de Dôme station, J. Atmos. Chem. 54, 267-281.

Pruppacher, H. R. and Klett, J. D., 1997: Microphysics of Clouds and Precipitation (2 ${ }^{\text {nd }}$ Edition), 954 pp., Kluwer Academic Publishers, Dordrecht, The Netherlands.

Putaud, J. -P., Raes, F., Van Dingenen, R., Brüggemann, E., Facchini, M. C., Decesari, S., Fuzzi, S., Gehrig, R., Hüglin, C., Laj, P., Lorbeer, G., Maenhaut, W., Mihalopoulos, N., Müller, K., Querol, X., Rodriguez, S., Schneider, J., Spindler, G., ten Brink, H., Torseth, K. and Wiedensohler, A., 2004: A European aerosol phenomenology -2 : chemical characteristics of particulate matter at kerbside, urban, rural and background sites in Europe, Atmos. Environ. 38, 2561-2577.

Raabe, G., 1996: Eine Laserphotolytische Studie zur Kinetic der Reaktionen des $\mathrm{NO}_{3}{ }^{-}$ Radikals in Wässriger Lösung, Cuvillier, Göttingen, Germany.

Ramaswamy, V., Boucher, O., Haigh, J., Hauglustaine, D., Haywood, J., Myhre, G., Nakajima, T., Shi, G. Y. and Solomon, S., 2001: Radiative forcing of climate change, 
in J. T. Houghton, Y. Ding, D. J. Griggs, M. Noguer, P. J. van der Linden, X. Dai, K. Maskell and C. A. Johnson (ed.), Climate Change 2001: The Scientific Basis. Contribution of working group I to the Third Assessment Report of the Intergovernmental Panel on Climate Change, Cambridge University Press, New York, pp. 349-416.

Saxena, P. and Hildemann, L. M., 1996: Water-soluble organics in atmospheric particles: a critical review of the literature and application of thermodynamics to identify candidate compounds, J. Atmos. Chem. 24, 57-109.

Sellegri, K. , 2002: Etude du processus d'activation des gouttelettes de nuage: Implications en chimie multiphases, $\mathrm{PhD}$ thesis, Joseph Fourier University, Grenoble, France.

Sellegri, K., Laj, P., Peron, F., Dupuy, R., Legrand, M., Preunkert, S., Putaud, J. -P., Cachier H. and Ghermandi, G., 2003a: Mass balance of free tropospheric aerosol at the Puy de Dôme (France) in winter, J. Geophys. Res. 108, 4333, doi:10.1029/2002JD002747.

Sellegri, K., Laj, P., Marinoni, A., Dupuy, R., Legrand, M. and Preunkert, S., 2003b: Contribution of gaseous and particulate species to droplet solute composition at the Puy de Dôme, France, Atmos. Chem. Phys. 3, 1509-1522.

Sellegri, K., Laj, P., Dupuy, R., Legrand, M., Preunkert, S. and Putaud, J. -P., 2003c: Size-dependent scavenging efficiencies of multicomponent atmospheric aerosols in clouds, J. Geophys. Res. 108, 4334, doi:10.1029/2002JD002749.

Smith, R. M. and Martell, A. E., 1976: Critical Stability Constants. Volume 4: Inorganic Complexes, Plenum Press, New York London.

Sorooshian, A., Varutbangkul, V., Brechtel, F. J., Ervens, B., Feingold, G., Bahreini, R., Murphy, S. M., Holloway, J. S., Atlas, E. L., Buzorius, G., Jonsson, H., Flagan, R. C. 
and Seinfeld, J. H., 2006: Oxalic acid in clear and cloudy atmospheres: Analysis of data from International Consortium for Atmospheric Research on Transport and Transformation 2004, J. Geophys. Res. 111, D23S45, doi:10.1029/2005JD006880.

Van Dingenen, R., Raes, F., Putaud, J. -P., Baltensperger, U., Charron, A., Facchini, M. C., Decesari, S., Fuzzi, S., Gehrig, R., Hansson, H. -C., Harrison, R. M., Hüglin, C., Jones, A. M., Laj, P., Lorbeer, G., Maenhaut, W., Palmgren, F., Querol, X., Rodriguez, S., Schneider, J., ten Brink, H., Tunved, P., Torseth, K., Wehner, B., Weingartner, E., Wiedensohler, A. and Wahlin, P., 2004: A European aerosol phenomenology -1 : physical characteristics of particulate matter at kerbside, urban, rural and background sites in Europe, Atmos. Environ. 38, 2561-2577.

Voisin, D., Legrand, M. and Chaumerliac, N., 2000: Scavenging of acidic gases ( $\mathrm{HCOOH}, \mathrm{CH}_{3} \mathrm{COOH}, \mathrm{HNO}_{3}, \mathrm{HCl}$, and $\mathrm{SO}_{2}$ ) and ammonia in mixed liquid-solid water clouds at the Puy de Dôme mountain (France), J. Geophys. Res. 105, 68176835.

Williams, J.E., Dentener, F.J. and van den Berg, A.R., 2002: The influence of cloud chemistry on HOx and Nox in the moderately polluted marine boundary layer: a 1-D modelling study, Atmos. Chem. Phys. 2, 277-302.

Wobrock, W., Flossmann, A. I., Monier, M., Pichon, J. -M., Cortez, L., Fournol, J. -F., Schwarzenböck, A., Mertes, S., Heintzenberg, J., Laj, P., Orsi, G., Ricci, L., Fuzzi, S., Brink, H. T., Jongejan P. and Otjes, R., 2001: The Cloud Ice Mountain Experiment (CIME) 1998: experiment overview and modelling of the microphysical processes during the seeding by isentropic gas expansion, Atmos. Res. 58, 231-265.

Wolke, R., Sehili, A. M., Simmel, M., Knoth, O., Tilgner, A. and Herrmann, H., 2005: SPACCIM: A parcel model with detailed microphysics and complex multiphase chemistry, Atmos. Environ. 39, 4375-4388. 
Yin, Y., Carslaw, K. S. and Feingold, G., 2005: Vertical transport of aerosols in a mixed-phase convective cloud and the feedback on cloud development, $Q$. J. $R$. Meteorol. Soc. 131, 221-245. 


\section{Figure captions}

Figure 1. Back-trajectory arriving at noon at the top of the Puy de Dôme and the corresponding vertical wind speed, the topography is indicated in grey and the summit of the Puy de Dôme by the black arrow. The simulation starts when the air parcel begins its lifting as indicated with the black dashed arrow.

Figure 2. Chemical composition of the four modes of aerosol particles for anthropogenic air mass sampled at the top of Puy de Dôme mountain, adapted from Sellegri et al. (2003a).

Figure 3. Fit of the observed aerosol mass distributions with four lognormal distributions for anthropogenic air mass sampled at the top of Puy de Dôme mountain, adapted from Sellegri et al. (2003a). The solid grey line is the distribution obtained from measurements (obtained by weighting), the dotted grey line is the fitted distribution, the solid black line is the first lognormal distribution for the Aitken mode, the dot-dashed black line is the second lognormal distribution for the accumulation mode 1, the dotted black line is the third lognormal distribution for the accumulation mode 2, and the dashed black line is the fourth lognormal distribution for the coarse mode.

Figure 4. Simulated phase partitioning between the gas, particulate and liquid phases in cloud. The contributions of activated particles, gas scavenging and chemical production are reported for the liquid phase.

Figure 5. Estimated phase partitioning from measurements for anthropogenic influence free tropospheric air masses between the gas, particulate and liquid phases in cloud 
calculated from concentrations from the RJI+Cascade Impactor (particulate), RJI+Mist chambers (intertitial gaz phase) and CDI (liquid phase). Further partitioning within the liquid phase between the gas-originating fraction and the particle-originating fraction are calculated from the CVI/CDI comparison. Gas concentrations are below detection limits for $\mathrm{HCl}, \mathrm{HNO}_{3}, \mathrm{SO}_{2}$ and $\mathrm{H}_{2} \mathrm{C}_{2} \mathrm{O}_{4}$, and thus their concentration are assimilated to detection limits. Adapted from Sellegri et al. (2003b). 
Table 1. Henry's law constant and equilibrium constants for oxalic acid, and oxalate oxidation and iron-oxalate chemistry in $\mathrm{M} 2 \mathrm{C} 2$ model. No temperature dependence (i.e. activation energy) is available for these equilibriums and reactions.

\begin{tabular}{|c|c|c|c|}
\hline Henry's law constant & & $\mathrm{H}\left(\mathrm{M} \mathrm{atm}^{-1}\right)$ & References \\
\hline $\mathrm{COOHCOOH}(\mathrm{g}) \leftrightarrow \mathrm{COOHCOOH}(\mathrm{w})$ & & $5.010^{8}$ & Saxena and Hilderman, 1996 \\
\hline Equilibrium constant & & $\mathrm{K}(\mathrm{M})$ & Reference \\
\hline $\mathrm{H}_{2} \mathrm{C}_{2} \mathrm{O}_{4} \leftrightarrow \mathrm{H}^{+}+\mathrm{HC}_{2} \mathrm{O}_{4}^{-}$ & & $5.610^{-2}$ & Smith and Martell, 1976 \\
\hline $\mathrm{HC}_{2} \mathrm{O}_{4}^{-} \leftrightarrow \mathrm{H}^{+}+\mathrm{C}_{2} \mathrm{O}_{4}^{2-}$ & & $5.4210-5$ & Smith and Martell, 1976 \\
\hline Reactions & & $\mathrm{k}_{298}\left(\mathrm{M}^{-\mathrm{n}+1} \mathrm{~s}^{-1}\right)$ & References \\
\hline $\mathrm{HC}_{2} \mathrm{O}_{4}^{-}+\mathrm{OH} \rightarrow \mathrm{C}_{2} \mathrm{O}_{4}^{-}+\mathrm{H}_{2} \mathrm{O}$ & (A1) & $4.710^{7}$ & Getoff et al., 1971 \\
\hline $\mathrm{C}_{2} \mathrm{O}_{4}{ }^{2-}+\mathrm{OH} \rightarrow \mathrm{C}_{2} \mathrm{O}_{4}^{-}+\mathrm{OH}^{-}$ & (A2) & $7.710^{6}$ & Getoff et al., 1971 \\
\hline $\mathrm{HC}_{2} \mathrm{O}_{4}^{-}+\mathrm{NO}_{3} \rightarrow \mathrm{NO}_{3}^{-}+\mathrm{H}^{+}+\mathrm{C}_{2} \mathrm{O}_{4}^{-}$ & (A3) & $6.810^{7}$ & Raabe, 1996 \\
\hline $\mathrm{C}_{2} \mathrm{O}_{4}^{2-}+\mathrm{NO}_{3} \rightarrow \mathrm{NO}_{3}^{-}+\mathrm{C}_{2} \mathrm{O}_{4}^{-}$ & (A4) & $2.210^{8}$ & Raabe, 1996 \\
\hline $\mathrm{HC}_{2} \mathrm{O}_{4}^{-}+\mathrm{Cl}_{2}^{-} \rightarrow \mathrm{C}_{2} \mathrm{O}_{4}^{-}+2 \mathrm{Cl}^{-}+\mathrm{H}^{+}$ & (A5) & $1.310^{6}$ & Estimated as in Ervens et al., 2003 \\
\hline $\mathrm{C}_{2} \mathrm{O}_{4}{ }^{2-}+\mathrm{Cl}_{2}^{-} \rightarrow \mathrm{C}_{2} \mathrm{O}_{4}^{-}+2 \mathrm{Cl}^{-}$ & (A6) & $4.010^{6}$ & Estimated as in Ervens et al., 2003 \\
\hline $\mathrm{HC}_{2} \mathrm{O}_{4}^{-}+\mathrm{SO}_{4}^{-} \rightarrow \mathrm{SO}_{4}{ }^{2-}+\mathrm{H}^{+}+\mathrm{C}_{2} \mathrm{O}_{4}^{-}$ & (A7) & $3.410^{5}$ & Buxton et al., 1999 \\
\hline $\mathrm{C}_{2} \mathrm{O}_{4}{ }^{2-}+\mathrm{SO}_{4}^{-} \rightarrow \mathrm{SO}_{4}{ }^{2-}+\mathrm{C}_{2} \mathrm{O}_{4}^{-}$ & (A8) & $1.010^{6}$ & Buxton et al., 1999 \\
\hline $\mathrm{C}_{2} \mathrm{O}_{4}^{-}+\mathrm{O}_{2} \rightarrow 2 \mathrm{CO}_{2}+\mathrm{O}_{2}^{-}$ & (A9) & $2.010^{9}$ & Estimated as in Ervens et al., 2003 \\
\hline$\left[\mathrm{Fe}\left(\mathrm{C}_{2} \mathrm{O}_{4}\right)_{2}\right]^{-}+\mathrm{hv} \rightarrow \mathrm{Fe}^{2+}+\mathrm{C}_{2} \mathrm{O}_{4}{ }^{2-}+\mathrm{C}_{2} \mathrm{O}_{4}^{-}$ & (A10) & calculated & Faust and Zepp, 1993 \\
\hline$\left[\mathrm{Fe}\left(\mathrm{C}_{2} \mathrm{O}_{4}\right)_{3}\right]^{3-}+\mathrm{hv} \rightarrow \mathrm{Fe}^{2+}+2 \mathrm{C}_{2} \mathrm{O}_{4}{ }^{2-}+\mathrm{C}_{2} \mathrm{O}_{4}^{-}$ & $(\mathrm{A} 11)$ & calculated & Faust and Zepp, 1993 \\
\hline $\mathrm{C}_{2} \mathrm{O}_{4}{ }^{2-}+\mathrm{Fe}^{3+} \rightarrow\left[\mathrm{Fe}\left(\mathrm{C}_{2} \mathrm{O}_{4}\right)\right]^{+}$ & (A12) & $7.510^{6}$ & $\begin{array}{c}\text { Estimated using stability constant: } \\
\text { Martell and Smith, } 1977\end{array}$ \\
\hline$\left[\mathrm{Fe}\left(\mathrm{C}_{2} \mathrm{O}_{4}\right)\right]^{+} \rightarrow \mathrm{C}_{2} \mathrm{O}_{4}{ }^{2-}+\mathrm{Fe}^{3+}$ & (A13) & $3.010^{-3}=\mathrm{k}_{15}$ & Estimated \\
\hline $\mathrm{C}_{2} \mathrm{O}_{4}{ }^{2-}+\left[\mathrm{Fe}\left(\mathrm{C}_{2} \mathrm{O}_{4}\right)\right]^{+} \rightarrow\left[\mathrm{Fe}\left(\mathrm{C}_{2} \mathrm{O}_{4}\right)_{2}\right]^{-}$ & (A14) & $1.8910^{4}$ & Martell and Smith, 1977 \\
\hline$\left[\mathrm{Fe}\left(\mathrm{C}_{2} \mathrm{O}_{4}\right)_{2}\right]^{-} \rightarrow \mathrm{C}_{2} \mathrm{O}_{4}{ }^{2-}+\left[\mathrm{Fe}\left(\mathrm{C}_{2} \mathrm{O}_{4}\right)\right]^{+}$ & $(\mathrm{A} 15)$ & $3.010^{-3}$ & Moorhead and Sutin, 1966 \\
\hline $\mathrm{C}_{2} \mathrm{O}_{4}{ }^{2-}+\left[\mathrm{Fe}\left(\mathrm{C}_{2} \mathrm{O}_{4}\right)_{2}\right]^{-} \rightarrow\left[\mathrm{Fe}\left(\mathrm{C}_{2} \mathrm{O}_{4}\right)_{3}\right]^{3-}$ & (A16) & $4.810^{1}$ & $\begin{array}{c}\text { Estimated using stability constant: } \\
\text { Martell and Smith, } 1977\end{array}$ \\
\hline$\left[\mathrm{Fe}\left(\mathrm{C}_{2} \mathrm{O}_{4}\right)_{3}\right]^{3-} \rightarrow \mathrm{C}_{2} \mathrm{O}_{4}{ }^{2-}+\left[\mathrm{Fe}\left(\mathrm{C}_{2} \mathrm{O}_{4}\right)_{2}\right]^{-}$ & (A17) & $3.010^{-3}=\mathrm{k}_{15}$ & Estimated \\
\hline
\end{tabular}


Table 2. Initial gas phase concentrations from Voisin et al., 2000.

\begin{tabular}{cc}
\hline Species & Gaseous concentration (ppbv) \\
\hline $\mathrm{N}_{2}$ & $7,8.10^{8}$ \\
$\mathrm{O}_{2}$ & $2,1.10^{8}$ \\
$\mathrm{H}_{2} \mathrm{O}$ & $5,7.10^{7}$ \\
$\mathrm{O}_{3}$ & 37 \\
$\mathrm{NO}$ & 0.9 \\
$\mathrm{NO}_{2}$ & 6.2 \\
$\mathrm{CH}_{4}$ & 1600 \\
$\mathrm{CO}$ & 100 \\
$\mathrm{HNO}_{3}$ & 0.15 \\
$\mathrm{HNO}_{2}$ & 0.054 \\
$\mathrm{H}_{2} \mathrm{O}_{2}$ & 0.07 \\
$\mathrm{HCHO}$ & 6 \\
$\mathrm{CH}_{3} \mathrm{OH}$ & 2.25 \\
$\mathrm{SO}_{2}$ & 0.45 \\
$\mathrm{HCOOH}$ & 0.28 \\
$\mathrm{NH}_{3}$ & 0.13 \\
$\mathrm{HCl}$ & 0.07 \\
\hline
\end{tabular}


Table 3. Initial physico-chemical properties of aerosol particles; the first three parameters are defined in equation (1), $\square_{\text {api }}$ is the density of aerosols for mode $\mathrm{i}, \square_{\mathrm{i}}$ is the number of dissociated ion for mode $i, \square_{i}$ is the mass fraction of soluble materials in mode $\mathrm{i}, \mathrm{M}_{\mathrm{api}}$ is the molar mass of mode i. The mass fraction of chemical species is related to soluble mass.

\begin{tabular}{|c|c|c|c|c|c|c|c|}
\hline Mode & $\mathrm{N}_{\text {api }}\left(\# \mathrm{~cm}^{-3}\right)$ & $\mathrm{a}_{\mathrm{mi}}(\mu \mathrm{m})$ & $\log \sigma \mathrm{i}$ & api $\left(\mathrm{g} \mathrm{cm}_{-3}\right)$ & $\square_{\mathrm{i}}$ & $\square_{\mathrm{i}}(\%)$ & $\mathrm{M}_{\mathrm{api}}\left(\mathrm{g} \mathrm{mole}^{-1}\right)$ \\
\hline 1 & 111.9 & 0.038 & 0.255 & 1.75 & 2 & 31 & 175 \\
\hline 2 & 4.2 & 0.205 & 0.278 & 1.74 & 2 & 40 & 274 \\
\hline 3 & 1.5 & 0.330 & 0.041 & 1.74 & 2 & 61.5 & 248 \\
\hline 4 & 0.026 & 1.300 & 0.301 & 1.75 & 2 & 65 & 272 \\
\hline Mode & Nitrate $(\%)$ & Ammonium (\%) & Sulphate (\%) & \multicolumn{2}{|c|}{ Formate (\%) } & Oxalate (\%) & Iron $(\%)$ \\
\hline 1 & 30 & 30.8 & 26.4 & \multicolumn{2}{|c|}{2.2} & 3.3 & 0 \\
\hline 2 & 29.6 & 18.2 & 35 & \multicolumn{2}{|c|}{1.2} & 1.8 & 0.1 \\
\hline 3 & 30 & 14.8 & 39.5 & \multicolumn{2}{|c|}{0.8} & 1.2 & 0.2 \\
\hline 4 & 43 & 2.7 & 19 & \multicolumn{2}{|c|}{2.5} & 3.7 & 0.8 \\
\hline
\end{tabular}


Table 4. Comparison of observed and simulated averaged $\mathrm{pH}$ value and concentrations in cloud water in $\mu \mathrm{g} \mathrm{L} \mathrm{L}^{-1}$, except for iron in $\mu \mathrm{M}$. Observed values are adapted from Marinoni et al., 2004 and from Parazols et al. (2006) for anthropogenic air mass sampled at the Puy de Dôme station.

\begin{tabular}{cccccccc} 
& $\mathrm{pH}$ & Nitrate & Ammonium & Sulphate & Formate & Oxalate & Iron $(\mu \mathrm{M})$ \\
\hline Observed & $3.7 \pm 0.4$ & $10702 \pm 6631$ & $3074 \pm 934$ & $5460 \pm 1584$ & $412 \pm 304$ & $155 \pm 114$ & $5.3 \pm 3.2$ \\
Simulated & 3.6 & 14880 & 2520 & 6940 & 920 & 360 & 1.9 \\
\hline
\end{tabular}


Table 5. Contribution to the concentrations of nitrate, sulphate, ammonium and formic acid in the liquid cloud droplet at the end of the simulation from activation of aerosol particles, from scavenging of gases and from chemical reactivity .

\begin{tabular}{ccccc} 
& Aerosols & Gas scavenging & \multicolumn{2}{c}{ Chemistry } \\
scavenging & Gas phase & $\begin{array}{c}\text { Aqueous phase } \\
\text { production }\end{array}$ \\
\hline Nitrate & 56 & 15.5 & 23 & 5.5 \\
Ammonium & 72.5 & 27.5 & 0 & 0 \\
Sulphate & 73 & 0 & 0 & 27 \\
Formate & 20 & 75 & 0 & 5 \\
\hline
\end{tabular}


Table 6. Contribution of gas scavenging, iron reactivity and other pathways in $\mathrm{OH}$ cloud droplets production for the reference simulation including iron-oxalate chemistry and a simulation neglecting oxalate chemistry.

\begin{tabular}{ccccc} 
& \multirow{2}{*}{ OH scavenging } & \multicolumn{2}{c}{ Iron reactivity } & \multirow{2}{*}{ Other pathways } \\
& & Iron(III) $+\mathrm{h} v$ & Fenton & \\
\hline Iron and oxalate & $57 \%$ & $26 \%$ & $4 \%$ & $13 \%$ \\
Iron & $36 \%$ & $55 \%$ & $2 \%$ & $7 \%$ \\
\hline
\end{tabular}


Click here to download line figure: Figure1.ppt




Aitken mode

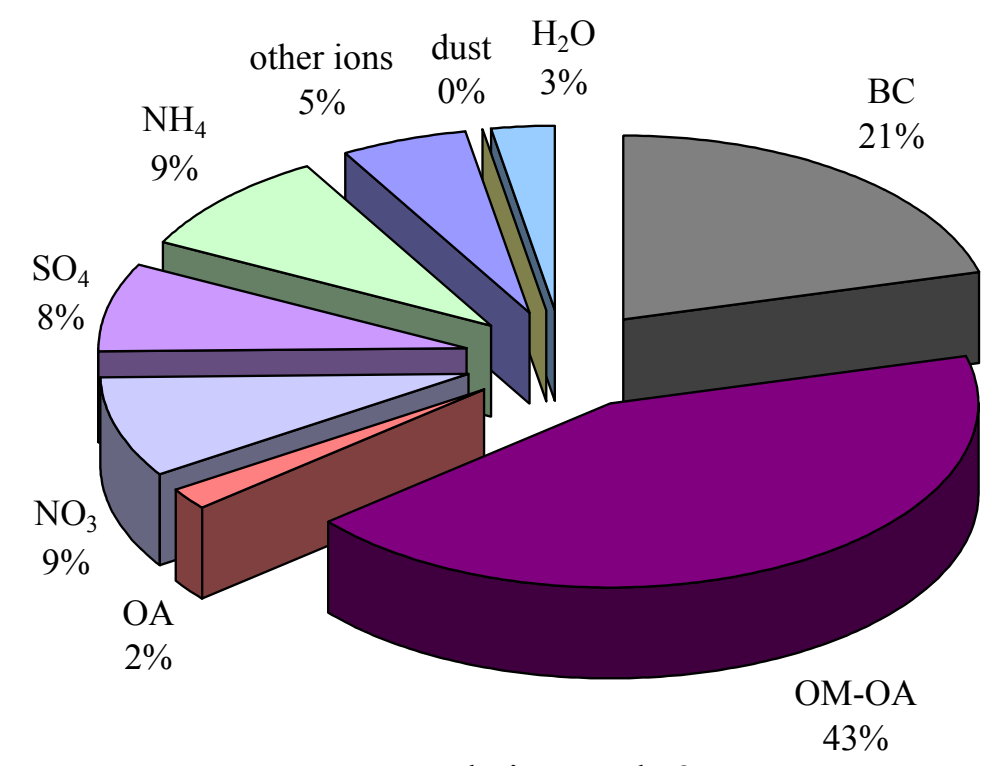

accumulation mode 2

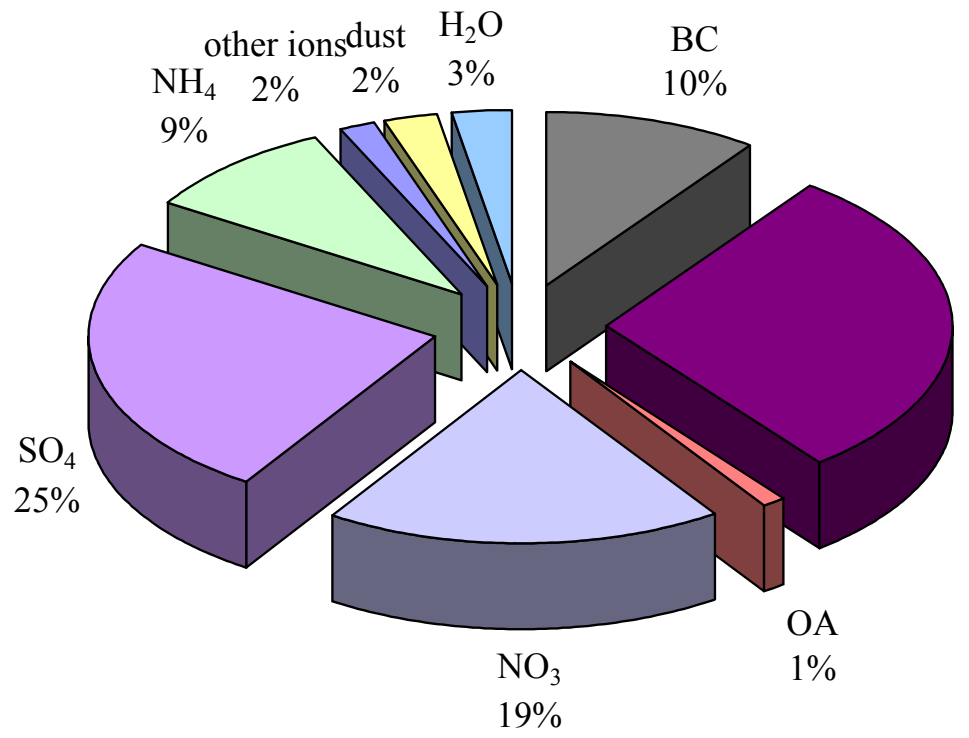

accumulation mode 1

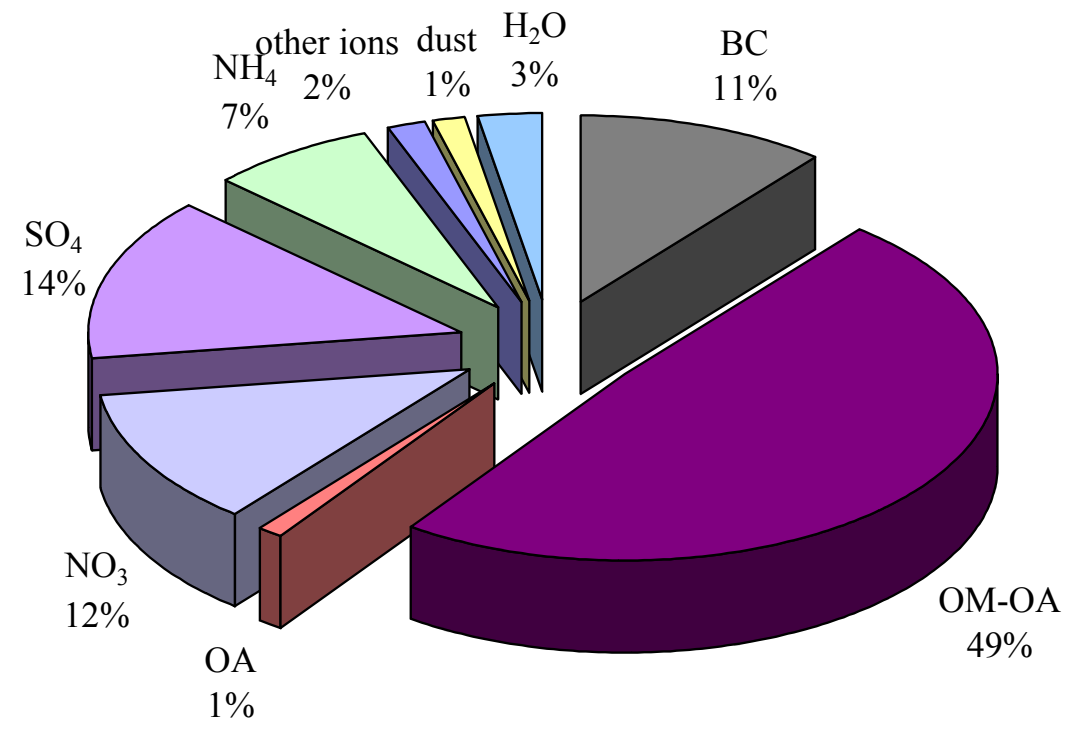

coarse mode

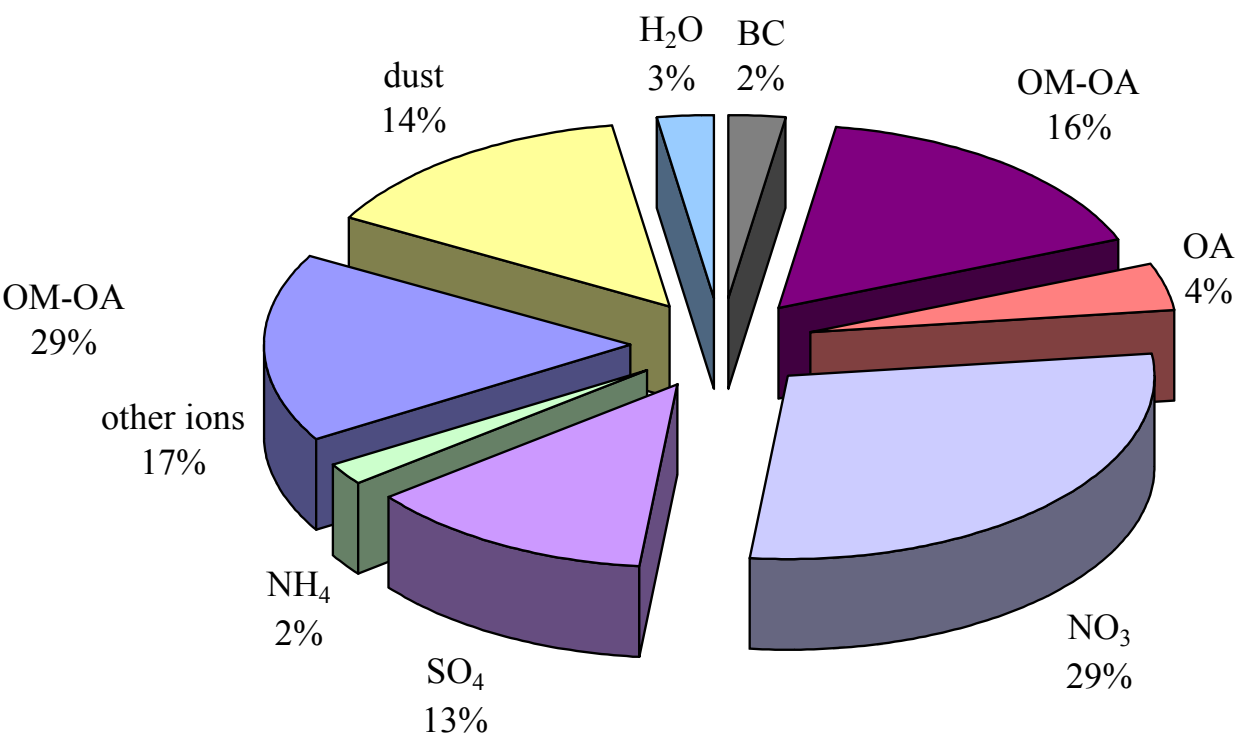


Click here to download line figure: Figure3.ppt

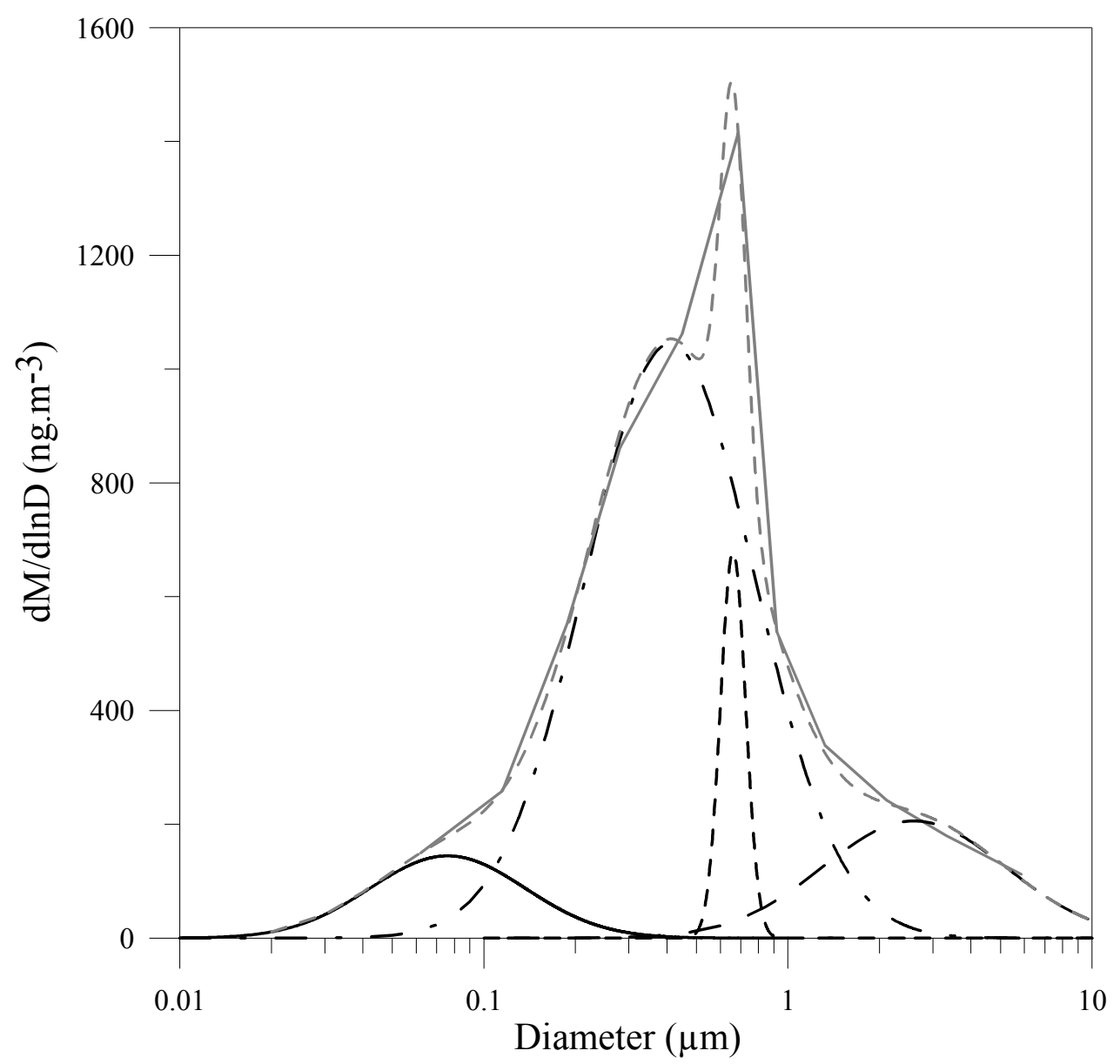





$\square$ Interstitial gas

$\square$ Liquid phase

Part-originating Liq.

Interstitial particles

血 Gas-originating Liq.

Chemical production 
Click here to download line figure: Figure5.ppt

$\mathrm{CH}_{3} \mathrm{COOH} / \mathrm{CH}_{3} \mathrm{COO}^{-}$

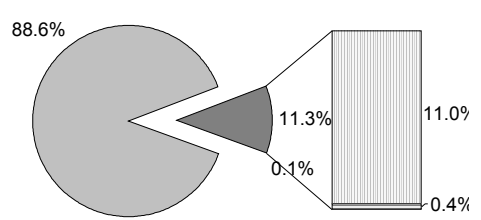

$\mathrm{SO}_{2} / \mathrm{SO}_{4}{ }^{2-}$

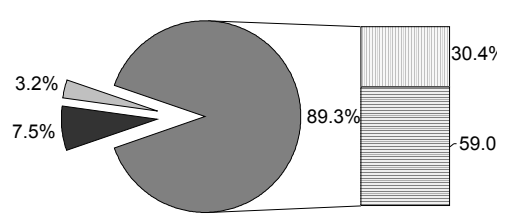

$\mathrm{HCOOH} / \mathrm{HCOO}^{-}$

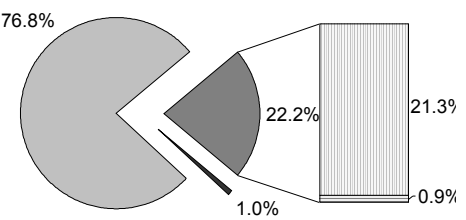

$\mathrm{H}_{2} \mathrm{C}_{2} \mathrm{O}_{4} / \mathrm{C}_{2} \mathrm{O}_{4}{ }^{2}$

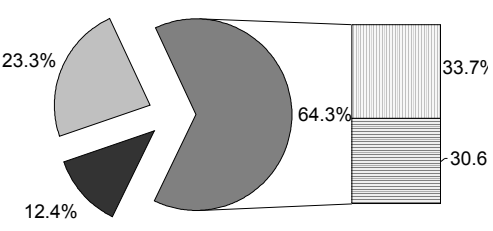

$\mathrm{HCl} / \mathrm{Cl}^{-}$



$\mathrm{NH}_{3} / \mathrm{NH}_{4}{ }^{+}$

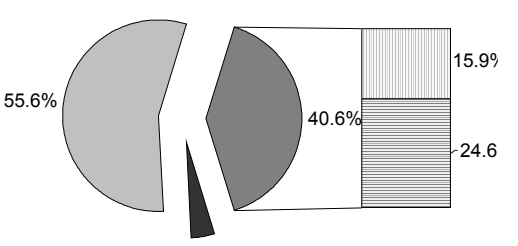

$\square$
$\square$
$\square$
$\square$
$\square$
$\mathrm{HNO}_{3} / \mathrm{NO}_{3}{ }^{-}$

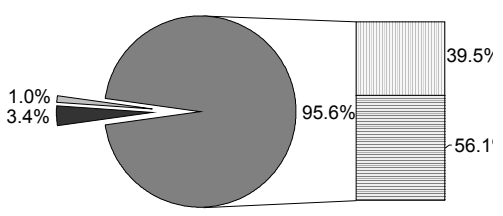

Interstitial gas Interstitial particles

Liquid phase gas-originating Liq part-originating Liq. 